\title{
Vertical Variability in Bark Hydrology for Two Coniferous Tree Species
}

\author{
Anna llek ${ }^{1,2 *}$, John T. Van Stan ${ }^{3}$, Karolina Morkisz ${ }^{2}$ and Jarosław Kucza ${ }^{2}$ \\ ${ }^{1}$ Department of Botany and Forest Habitats, Faculty of Forestry and Wood Technology, Poznań University of Life Sciences, \\ Poznań, Poland, ${ }^{2}$ Department of Forest Utilization, Engineering and Forest Technology, Faculty of Forestry, University \\ of Agriculture in Krakow, Krakow, Poland, ${ }^{3}$ Department of Biological, Geological, and Environmental Sciences, Cleveland \\ State University, Cleveland, $\mathrm{OH}$, United States
}

\section{OPEN ACCESS}

Edited by:

Heidi Asbornsen,

University of New Hampshire,

United States

Reviewed by:

Paolo Giordani,

University of Genoa, Italy

Brett Wolfe,

Louisiana State University Agricultural Center, United States

*Correspondence:

Anna llek

anna.ilek@up.poznan.pl

Specialty section:

This article was submitted to

Forest Hydrology,

a section of the journal

Frontiers in Forests and Global

Change

Received: 30 March 2021

Accepted: 24 September 2021

Published: 21 October 2021

Citation:

Ilek A, Van Stan JT, Morkisz K and

Kucza J (2021) Vertical Variability

in Bark Hydrology for Two Coniferous

Tree Species.

Front. For. Glob. Change 4:687907.

doi: 10.3389/ffgc.2021.687907
As the outermost layer of stems and branches, bark is exposed to the influence of atmospheric conditions, i.e., to changes in the air's relative humidity and wetting during storms. The bark is involved in water interception by tree canopies and stemflow generation, but bark-water relations are often overlooked in ecohydrological research and insufficiently understood. Relative to other canopy ecohydrological processes, little is known about vertical variation in bark properties and their effect on bark hydrology. Thus, the objective of this study was to analyze changes in physical properties (thickness, outer to total bark thickness ratio, density, and porosity) and hydrology (bark absorbability, bark water storage capacity, and hygroscopicity) vertically along stems of Norway spruce [Picea abies (L.) Karst.] and silver fir (Abies alba Mill.) trees. Our null hypotheses were that bark hydrology is constant both with tree height and across measured physical bark properties. We found that bark thickness and the ratio of outer-to-total bark thickness decreased with tree height for both species, and this was accompanied by an increase in the bark water storage capacity. In contrast, the bark's density, porosity, and hygroscopicity remained relatively constant along stems. These results inform ecohydrological theory on water storage capacity, stemflow initiation, and the connection between the canopy water balance and organisms that colonize bark surfaces.

Keywords: forest hydrology, bark water storage capacity, bark hygroscopicity, Picea abies (L.) H. Karst., Abies alba (Mill.)

\section{INTRODUCTION}

When rain falls over forests, a hydrologically and ecologically relevant portion of that water (up to several $\mathrm{mm}$ event ${ }^{-1}$, depending on storm and canopy conditions) is retained on the canopy's leaves, epiphytes, and bark (Klamerus-Iwan et al., 2020). This canopy water storage fuels a major part of the Earth's terrestrial evaporation flux by returning rainwater back to the atmosphere as canopy interception (Porada et al., 2018). Canopy interception and the resulting changes in top-of-atmosphere albedo (i.e., related cloud formation) has been estimated to impact air temperatures by $-0.6^{\circ} \mathrm{C}$ globally and $-1.9^{\circ} \mathrm{C}$ regionally (Davies-Barnard et al., 2014) and can provide city-to-watershed scale stormwater ecoservices valued at millions (of USD) year $^{-1}$ 
(Nowak et al., 2020). Precipitation stored on wet leaves, epiphytes, and bark may be taken up by plants - and recent interest in these ecohydrological processes is growing (Berry et al., 2019; Aubrey, 2020; Carmichael et al., 2020; Miller et al., 2021). Water storage dynamics in canopy habitats have been linked to various ecological processes of societal importance. For example, the timing and extent of leaf wetness can influence plant pathogen infection and transport (DeBary, 1853; Rowlandson et al., 2015). Rainwater storage dynamics in pitcher-like leaves (phytotelmata) or in treeholes (dendrotelmata) can inform mosquito management (Maguire, 1971; Anosike et al., 2007). The dynamics of inner (living portion of) bark water storage have been linked to a suite of plant functions (Rosell et al., 2015; Wolfe and Kursar, 2015; Loram-Lourenco et al., 2020). However, research on the outer (non-living) bark's capacity and filling-and-emptying dynamics is comparatively under-represented.

Based on the available observations to date, bark merits improved representation in the canopy water balance. Bark is present all year round in woody ecosystems, unlike leaves, and its specific water storage capacity can be larger than leaves from the same species (Klamerus-Iwan et al., 2020). There are two important caveats regarding these bark water storage capacity estimates. First, most past estimates come from methods that rely on samples taken near the stem base (e.g., Liu, 1998; Llorens and Gallart, 2000; Van Stan et al., 2016); however, the vertical variability of bark structure in single trees can be visually striking. When examined, this vertical bark structural variability has been found to result in substantial variability in bark water storage capacity, where the capacity of the lower bark was roughly double that of the upper-canopy bark (Levia and Wubbena, 2006). Characterizing the vertical variability in bark water storage capacity may shed light on the dynamics of multiple rainwater drainage pathways through tree canopies (i.e., branchflow, throughfall drip points, and stemflow). The upper canopy's bark water storage will influence the generation of branchflows and throughfall drip points (Herwitz, 1987; Van Stan et al., 2021). Along the lower portion of the stem, bark water storage can influence the generation of stemflow (Zhang et al., 2021). To advance understanding of this topic, this study examines vertical variability in bark water storage capacity (and other hydrological parameters) for two common tree species \{Norway spruce [Picea abies (L.) Karst.] and silver fir trees (Abies alba Mill.)\} alongside bark physical traits. The second caveat is that most of the past bark water storage capacity estimates assume there is no partial filling of this storage by water vapor during dry (or non-rainy) periods (Ilek et al., 2017b, 2021).

To understand the timing of water receipt below canopies via throughfall drip points and stemflow, it is not only important to know (i) how much water the bark can store and (ii) how this storage varies vertically - we must also understand (iii) how much of the water storage capacity is available for interception prior to the storm. One (rarely researched) way in which bark water storage (at any height in the canopy) may remain at an intermediate saturation state between storms is via bark's passive exchange with water vapor (i.e., hygroscopicity). Previous work has found that a meaningful fraction of bark water storage capacity may be occupied by hygroscopic water (Ilek et al., 2017b, 2021). For several tree species in a continental, temperate forest site, hygroscopic water within bark could account for $10-30 \%$ of bark water storage capacity (Ilek et al., 2017b). At a more humid (subtropical) forest site, Ilek et al. (2021) found that hygroscopic water could account for an even greater fraction of bark water storage capacity, even exceeding $60 \%$ at times. However, our understanding of bark hygroscopicity shares an uncertainty (that is unresearched, to the knowledge of the authors) with our understanding bark water storage capacity: its vertical variability. To advance understanding on this topic, our vertical assessment of bark water storage capacity is complemented by a vertical assessment of the hygroscopic fraction of this storage capacity for two study tree species.

The vertical sampling of bark and estimation of its variability in water storage capacity and hygroscopic fraction, alongside its physical characteristics, enabled the testing of various hypotheses. The null hypotheses tested in this study include: (1) bark water storage capacity is constant with height; (2) hygroscopic water represents a similar fraction of this storage capacity with height; (3) bark water absorbability and absorption rates are constant with height; and (4) these bark hydrologic properties are constant across measured physical bark properties (i.e., porosity, bulk density, and thickness). Rejecting these null hypotheses would suggest physical mechanisms exist that vertically drive bark water storage and its hygroscopic fraction for these study species, meriting further research on this topic and, where confirmed, its integration into canopy water balances.

\section{MATERIALS AND METHODS}

\section{Study Area and Bark Sample Collection}

Bark samples were collected from felled Norway spruce [Picea abies (L.) Karst.] and silver fir trees (Abies alba Mill.) located in the Beskid Żywiecki Mountains $\left(49.9211^{\circ} \mathrm{N}, 19.3606^{\circ} \mathrm{E}\right)$ within the State Forests (Jeleśnia Forest District) in southern Poland, at heights ranging from about 800 to 840 masl (Figure 1). The study area belongs to the Carpathian climate zone situated in a temperate climate area. The average annual temperature is $5^{\circ} \mathrm{C}$, and the average annual precipitation is $1095 \mathrm{~mm}$. The average temperature and precipitation within the growing season are $14^{\circ} \mathrm{C}$ and $450 \mathrm{~mm}$, respectively. Dominant canopy trees at the site include Norway spruce, silver fir, European beech (Fagus sylvatica L.), and in some places, sycamore maple (Acerpseudoplatanus L.), and European larch (Larix decidua Mill.) ${ }^{1}$.

We chose three lichen-free and bark beetle-free trees per species with stem diameters at breast height between 34 and $39 \mathrm{~cm}$. After cutting down the trees, we measured their length and collected rectangular total bark samples every 1-2 m from the bottom to the trees' top using a knife, chisel, and hammer. The location of a given bark sample on a tree stem was expressed as a proportion of tree height, i.e., as a ratio of the distance measured from the bark sampling place to the tree's bottom by the stem

\footnotetext{
${ }^{1}$ www.bdl.lasy.gov.pl/portal/mapy-en
} 


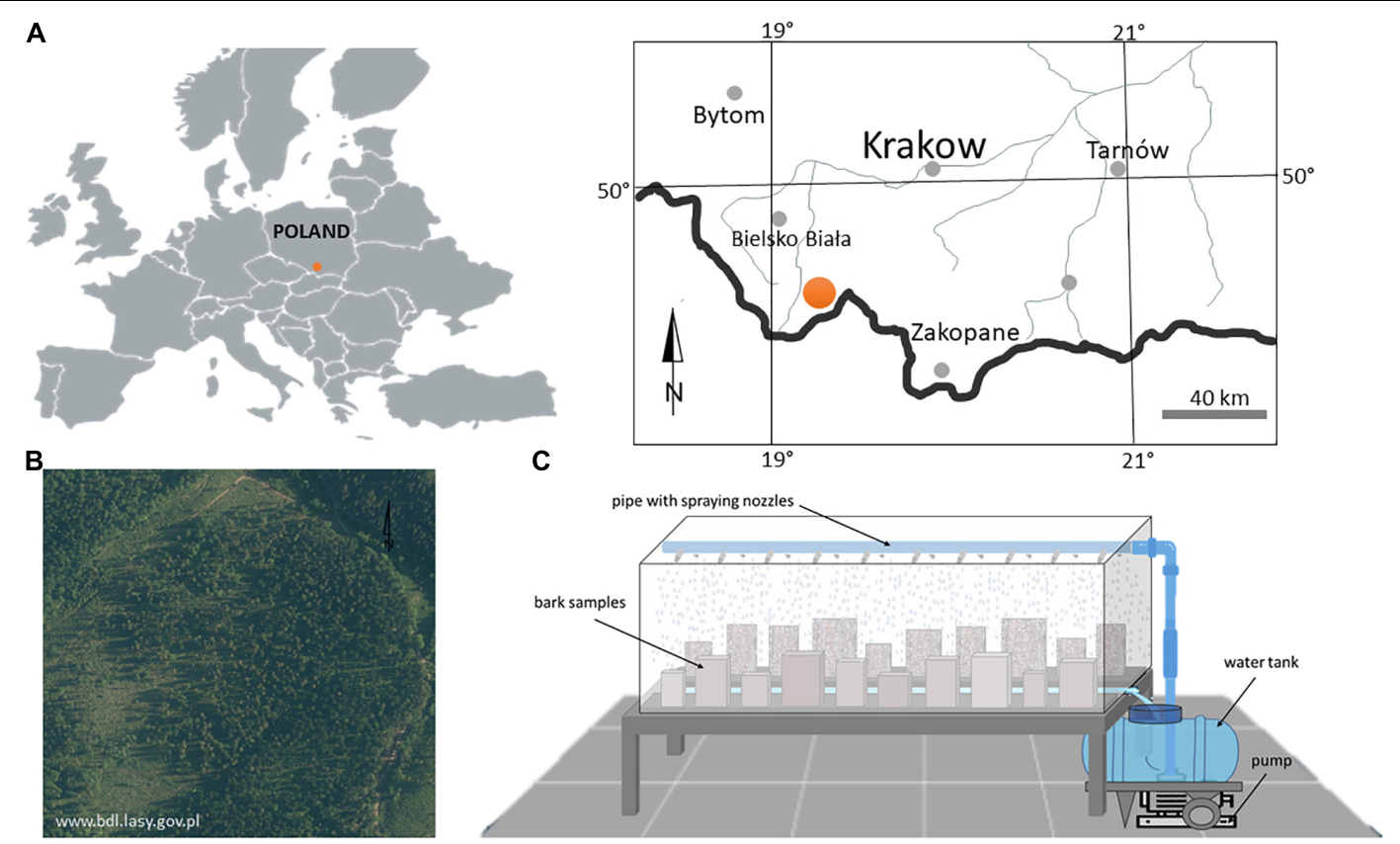

FIGURE 1 | Location of the study area (A) with a view of the stand where bark samples were collected (B) and rainfall simulator construction (C).

length. In total, we collected 56 samples of fir bark and 63 samples of spruce bark with an approximate area of $20-100 \mathrm{~cm}^{2}$, and each sample was classified by their height on the stem: bottom (0-33\% of tree height), middle (34-66\% of tree height), or top (67-100\% of tree height). Additionally, we collected several dozen smaller samples with an area of about $5 \mathrm{~cm}^{2}$ from each of the three sections of all trees.

\section{Laboratory Tests}

We determined bark absorbability, water absorption rate, bark water storage capacity, bark hygroscopicity, the ratio of bark hygroscopicity and water storage capacity, bark thickness, outer to total bark thickness ratio, bulk density, and total porosity of bark during laboratory tests. All bark samples were first oven-dried at $35^{\circ} \mathrm{C}$ to constant mass, and then we measured total, outer, and inner bark thickness using a digital caliper. Next, all internal and side surfaces of rectangular bark samples with an area of $20-100 \mathrm{~cm}^{2}$ were sealed with colorless silicon (Soudal) and dried at $35^{\circ} \mathrm{C}$ again. These samples were used to determine bark absorbability, water absorption rate, and bark water storage capacity under rainfall simulation conditions. The same procedure was applied to the one part of smaller bark samples $\left(\sim 5 \mathrm{~cm}^{2}\right)$ that were used to determine bark hygroscopicity. We applied silicon to seal the areas of bark samples that would not be exposed in situ (i.e., the inner tangential and radial sides of the bark samples) and to ensure water absorption only through the bark's outer layer during particular experiments.

A portion of bark samples was not sealed with silicone to allow water absorption estimates per the commonly used submersion methods of past research. In this case, measurement of bark absorbability began by determining the average time of water absorption by non-silicone bark samples with an area of $\sim 5 \mathrm{~cm}^{2}$ collected from the bottom, middle, and top parts of individual trees (we used on average 50 bark samples per individual part of each tree species). After drying the bark at $35^{\circ} \mathrm{C}$, the samples were immersed in water and covered from above with a damp cotton material. The time of water absorption was measured from the moment the bark samples were immersed in water until bark fell to the bottom of the beaker, i.e., until the given bark sample reached a density $>1 \mathrm{~g} \mathrm{~cm}^{-3}$ (Kucza and Urbaś, 2005; Ilek et al., 2019). The samples that had sunk to the bottom of the beaker were removed at least once a day, and then we determined their mass, their volume by the displacement of water in a graduated cylinder and their dry mass after drying at $105^{\circ} \mathrm{C}$. Based on dry mass, $m(\mathrm{~g})$, and volume of bark, $v\left(\mathrm{~cm}^{3}\right)$, we calculated its bulk density, $\rho_{d}\left(\mathrm{~g} \mathrm{~cm}^{-3}\right)$, according to the equation:

$$
\rho_{d}=m / v
$$

Before determining the sunken bark samples' mass and volume, we removed excess water from their surface using a moist paper towel. The average time of water absorption by non-silicone samples of fir and spruce bark from the bottom, middle, or top part of trees was calculated as the arithmetic means of the water absorption time achieved by all samples from a given part of trees per individual species.

The bark absorbability $B W A(\mathrm{~mm})$ and rate of water absorption $R W A\left(\mathrm{~mm} \mathrm{~h}^{-1}\right)$ by non-silicone bark samples were calculated according to the equations:

$$
B W A=\frac{M-m}{v} \cdot 10
$$




$$
R W A=B W A / t
$$

where $M$ is the mass of bark sample at the moment it reached a density $>1 \mathrm{~g} \mathrm{~cm}^{-3}(\mathrm{~g}), m$ is the dry mass of bark sample (g) ( $M$ $m$ corresponds to the volume of water stored by bark, assuming a water density of $1 \mathrm{~g} \mathrm{~cm}^{-3}$ ), $v$ is the volume of bark sample $\left(\mathrm{cm}^{3}\right), 10$ is a factor of conversion into $\mathrm{mm}$ of water in bark with a thickness of $1 \mathrm{~cm}$, and $t$ is the time after which the sample reached a density $>1 \mathrm{~g} \mathrm{~cm}^{-3}(\mathrm{~h})$.

We used the pycnometer method and $99.8 \%$ ethyl alcohol to determine the specific density of bark (Ilek et al., 2017b, 2021). Based on specific density $\rho_{s}$ and bulk density $\rho_{d}$, we calculated the total porosity of bark $(\Phi)$ according to the equation:

$$
\Phi=\frac{\rho_{s}-\rho_{d}}{\rho_{s}}
$$

After determining the average time of water absorption, bark absorbability, and water absorption rate by the non-silicone bark samples, we determined the bark water storage capacity, bark absorbability, and water absorption rate by bark samples sealed with silicone with an area ranging from 20 to $100 \mathrm{~cm}^{2}$. In determining these parameters, we assumed that: (1) water is absorbed only by the bark's outer layer under simulated rainfall conditions, and (2) during a rainfall event, water can flow freely (gravitationally) down the bark surface.

Rainfall simulations took place in a closed tunnel, $70 \mathrm{~cm}$ high, $160 \mathrm{~cm}$ long, and $60 \mathrm{~cm}$ wide, made of PVC plates with a steel gutter-shaped bottom draining excess water from the tunnel (Figure 1C). There was a PVC pipe with 20 spraying nozzles in the upper part of the tunnel, connected to a pump that pumped water from a tank. The rainfall rate was $10 \pm 1 \mathrm{~mm} \mathrm{~h}^{-1}$. During rainfall simulation experiments, the bark samples were positioned vertically, which allowed gravitational drainage of water from the bark surface during a rainfall event. The bark samples were sprinkled for $10 \mathrm{~h} \mathrm{day}^{-1}$, and in the intervals between rainfall, they were stored in desiccators partially filled with water, in which the relative air humidity was $100 \%$. The spraying time needed to determine the bark absorbability by silicone bark samples, according to Eq. 2, depended on the average time of water absorption obtained for non-silicone bark from individual parts and tree species (Table 1). The water absorption rate of silicone samples was calculated analogously to Eq. 3, where the $t$-value was constant for each part of the given tree species and corresponded to the average time of water absorption non-silicone samples (Table $\mathbf{1}$ ).

Bark water storage capacity was determined assuming the same time of sprinkling over the silicone bark samples with water, amounting to 7 days (Ilek et al., 2017b, 2021). Therefore, a 10-h rainfall was simulated for 7 days $(170 \mathrm{~h})$. After the last rainfall simulation event, bark samples were also left in a vertical position in the desiccator until the next day, and then samples were weighed, dried at $105^{\circ} \mathrm{C}$, and weighed again. The bark water storage capacity $B W S C(\mathrm{~mm})$ was calculated according to the equation:

$$
B W S C=\frac{M-m}{m / \rho_{d}} \cdot 10
$$

TABLE 1 | Average time of water absorption by non-silicone bark samples (days) where letters denote difference among parts and tree species based on the Kruskal-Wallis test $(p<0.05)$.

\begin{tabular}{lccccc}
\hline Species & Part of tree & Mean \pm SE & Median & Min & Max \\
\hline Norway spruce & Bottom & $7.4 \pm 0.1$ & $7.0^{a}$ & 1.7 & 15.0 \\
& Middle & $5.6 \pm 0.2$ & $5.7^{b}$ & 1.7 & 13.0 \\
& Top & $3.5 \pm 0.3$ & $2.7^{c d}$ & 1.0 & 8.6 \\
Silver fir & Bottom & $7.8 \pm 0.4$ & $6.9^{a b}$ & 0.9 & 19.7 \\
& Middle & $4.5 \pm 0.4$ & $2.2^{c}$ & 0.9 & 17.9 \\
& Top & $2.3 \pm 0.2$ & $1.9^{d}$ & 0.9 & 7.8 \\
\hline
\end{tabular}

where $M$ is the mass of bark sample after $170 \mathrm{~h}$ of rainfall simulation $(\mathrm{g}), m$ is the dry mass of bark sample $(\mathrm{g}), \rho_{d}$ is the average bulk density of spruce or fir bark calculated according to Eq. $1\left(\mathrm{~g} \mathrm{~cm}^{-3}\right)$, and 10 is a conversion factor to result in $\mathrm{mm}$ of water in bark with a thickness of $1 \mathrm{~cm}$.

To determine the variation in the bark hygroscopicity along stems of individual tree species, we used silicone-secured bark samples with an area of about $5 \mathrm{~cm}^{2}$ (56 and 63 samples of fir and spruce bark, respectively). Dried at $35^{\circ} \mathrm{C}$ bark samples were weighed and put into a desiccator partially filled with water, where a relative air humidity was 100\% (Ilek et al., 2017b, 2021). The bark samples were weighed every day until the further storage of bark samples in the desiccator no longer increased their mass, and then the samples were dried at $105^{\circ} \mathrm{C}$. The bark hygroscopicity $S_{H}$ was determined analogously to Eq. 5 . Based on $S_{H}$ and $B W S C$, we calculated the percentage proportion of bark hygroscopicity in bark water storage capacity $\left(C_{S H}\right)$.

\section{Statistical Analysis}

The statistical analysis and associated graphics were performed in Statistica 13.3 PL (StatSoft Inc.). We used the Mann-Whitney $\mathrm{U}$ test to compare the physical and hydrological properties of bark (regardless of tree part) between tree species. Significant differences in bark properties between the bottom, middle, and top parts of trees were tested by non-parametric Kruskal-Wallis test and one-way ANOVA (with post hoc Tukey test) after the previous checking of normality by the Shapiro-Wilk test and equality of variance by the Levene's test. We adopted a general linear model (GLM) to investigate the effect of the part of tree and the effect of tree species on bark properties and hydrology. All tests were performed at a significance level of 0.05 .

\section{RESULTS}

\section{Interspecific Differences in Hydro-Physical Properties of Bark}

The physical and hydrological properties of bark samples differed between Norway spruce and silver fir (Figure 2). The thickness and bulk density of spruce bark were 32.4 and $25.9 \%$ lower than fir bark, while total porosity was significantly higher $(p<0.001$, Figure 2). The ratio of spruce outer-to-total bark thickness was 0.44 , on average, while the ratio of outer to total bark thickness in silver fir bark was 0.23 on average. No significant differences were 

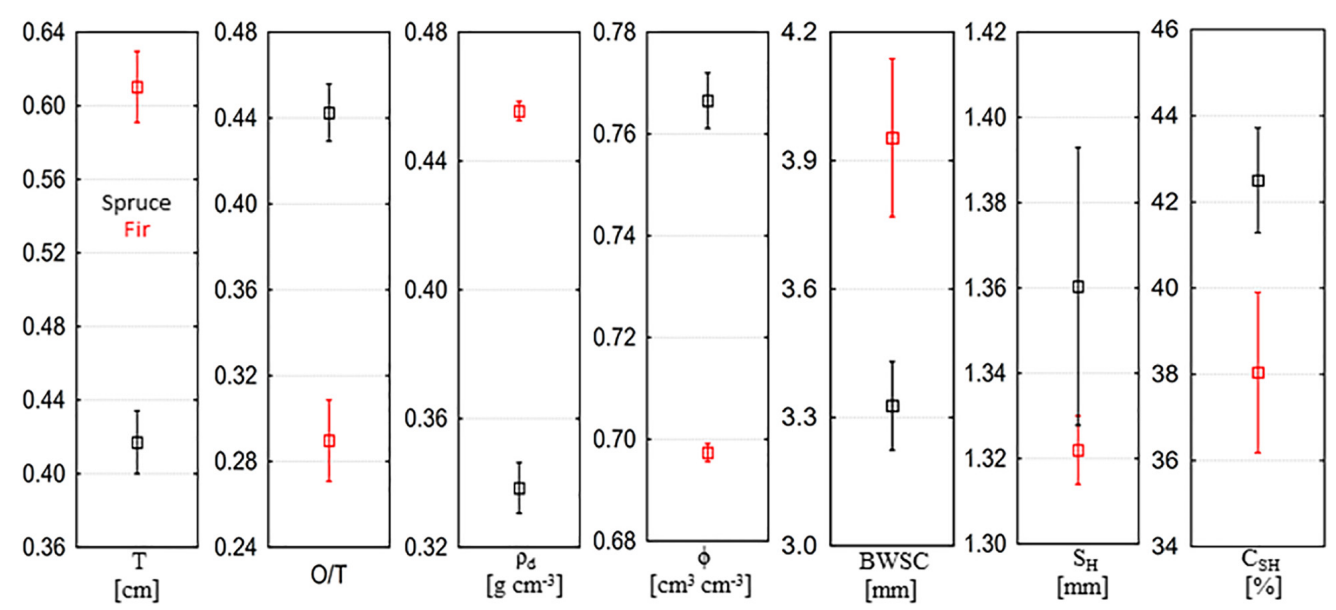

FIGURE 2 | Physical and hydrological properties of Norway spruce and silver fir bark, where $T$ is the thickness of total bark, O/T is the outer to total bark thickness ratio, $\rho_{d}$ is the bulk density, $\phi$ is the total porosity, $B W S C$ is the bark water storage capacity, $S_{H}$ is the bark hygroscopicity, and $C_{S H}$ is the proportion of bark water storage capacity occupied by bark hygroscopicity (mean $\pm \mathrm{SE}$ ).

observed in bark hygroscopicity between species $(p=0.284)$. The water storage capacity of spruce bark was significantly lower than the water storage capacity of fir bark $(p=0.018)$, on average by $15.8 \%$ (Figure 2 ). The proportion of bark water storage capacity occupied by bark hygroscopic water ranged from 17.8 to $69.5 \%$ and was significantly higher in spruce bark than in fir bark $(p=0.033)$.

\section{Vertical Variation in Bark Properties and Hydrology}

The average time of water absorption by non-silicone bark samples decreased along the stem, and in the top part of trees, it was by 52.7 and $70.5 \%$ lower compared to the bottom part of Norway spruce and silver fir trees, respectively (Table 1). The absorbability of non-silicone spruce bark ranged from 4.8 to $8.4 \mathrm{~mm}$ and was significantly higher than the absorbability of non-silicone fir bark $(p<0.001)$, on average by $17.5 \%$ (Figure 3A). In both species, the bark secured with silicone, which absorbed water only through the outer layer, achieved lower absorbability than the non-silicone bark. These differences were more significant in spruce than in fir (Figure 3A). During the absorption of water only by the outer bark layer, the vast majority of samples could not exceed the density of $1 \mathrm{~g} \mathrm{~cm}^{-3}$ (Figure 3C). Wet bulk density achieved by silicone fir bark samples was significantly higher than the density achieved by silicone spruce bark samples $(p=0.002)$, on average by $11.9 \%$. In both species, the rate of water absorption differed significantly between the individual tree parts $(p<0.001)$ and increased from bottom to top, in the case of both non-silicone and silicone bark (Figure 3B). We found the smallest differences in the average water absorption rate between non-silicone and silicone bark in the bottom and middle parts of the spruce trees, while the greatest differences were in the middle part of the fir trees (Figure 3B). Interestingly, the rate of water absorption by nonsilicone fir bark was on average $40.6 \%$ higher than that of non-silicone spruce bark; that difference in the case of silicone bark was only $4.8 \%$.

The water storage capacity of the spruce bark in the top part was significantly higher than the bark water storage capacity from the bottom $(p=0.001)$ and middle part of trees $(p<0.001)$, on average by 22.8 and $30.3 \%$, respectively (Figure 4A). We did not find such differences between the bottom and middle parts $(p=0.612)$. In silver fir, the bark water storage capacity in the top part was on average $12.8 \%$ higher than in the middle part and as much as $50.2 \%$ higher than in the bottom part of trees.

The spruce and fir bark's hygroscopicity ranged from 1.0 to $1.9 \mathrm{~mm}$ and 1.2 to $1.5 \mathrm{~mm}$. The hygroscopicity of the spruce bark from the bottom part was significantly higher than that of the middle part of trees $(p=0.020)$ (Figure 4A). In turn, the hygroscopicity of fir bark from the top part of trees was 5.1 and $4.4 \%$ lower than the hygroscopicity of the bark from the middle and bottom parts, respectively. The contribution of bark hygroscopicity in the bark water storage capacity varied between species (Figure 4B). This contribution ranged from 17.8 to $62.0 \%$ in spruce bark and differed significantly between individual tree parts $(p<0.001)$, assuming the highest values in the middle part and the lowest in the top part. In turn, in the case of fir, the contribution of hygroscopicity in the bark water storage capacity differed significantly between the bottom and middle part $(p<0.001)$ and the bottom and top part $(p<0.001)$, decreasing toward the top of the trees. The smallest differences in the contribution of bark hygroscopicity between the spruce and fir bark were observed in the bottom part and the largest in the middle part of trees (Figure 4B).

In both species, the thickness of the total bark decreased from bottom to top of trees (Figure 5). The thickness of spruce bark in the top part was on average $28.9 \%$ lower than the thickness in the bottom part, and in the case of fir, this difference amounted to $48.8 \%$. The thickness of fir bark in the bottom and middle parts was significantly higher than the thickness of spruce bark ( $p<0.001$ and $p=0.007$, respectively). We found no significant 


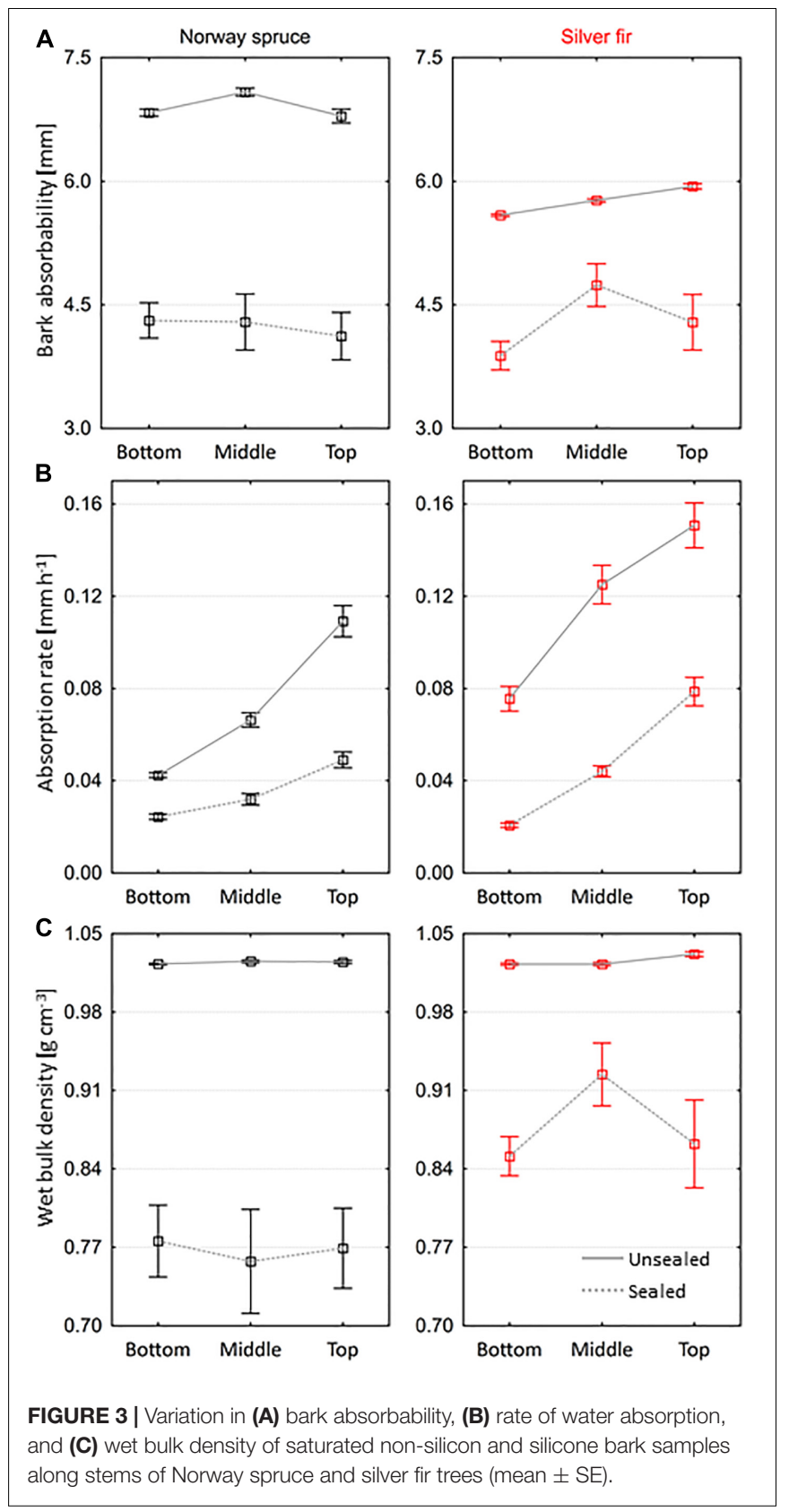

differences in bark thickness in the top part between species. We observed changes in the outer to total bark thickness ratio along tree stems in both tree species (Figure 5). In the top part of spruce and fir trees, bark contained 54.5 and $74.8 \%$ less outer bark than in the bottom. Fir bark contained less outer bark than spruce in all parts of trees, on average by $48.2 \%$ in the bottom, $53.5 \%$ in the middle, and $71.3 \%$ in the top part. We found no significant differences in bulk density and total porosity between parts of trees, both in spruce and fir trees (Figure 5). The bulk density of fir bark from the bottom, middle, and top parts was significantly higher than spruce bark, on average by $25.5,24.2$, and $24.5 \%$, respectively. In the bottom and middle parts, the total porosity of fir bark was significantly lower than spruce bark $(p<0.001)$.
No differences were observed in the total porosity of bark in the top part between both species.

The GLM analysis confirmed the influence of tree parts and tree species on some hydro-physical properties of bark (Table 2).

\section{DISCUSSION}

For the species in this study, vertical variability in BWSC was significant (Figure 4A), rejecting hypothesis 1. Moreover, vertical trends in BWSC differed between the species and total BWSC was greater for fir than for spruce (Figure 2). Per the measured physical traits, the interspecific differences in water storage may be driven by the thicker bark; after all, for fir bark compared to spruce, overall $\Phi$ and $\rho_{d}$ were lower and higher (Figure 2), respectively, and O:T was smaller at all heights (Figure 5). Interspecific variability in total BWSC has been ascribed to differences in bark thickness in past comparative studies of tree species across climates and natural forest types (Herwitz, 1985; Levia and Herwitz, 2005; Van Stan et al., 2016; Ilek et al., 2017b, 2021; Campellone, 2018). Few studies have considered bark physical traits (beyond thickness) in assessing the drivers of BWSC variability across species (Van Stan et al., 2016; Ilek et al., 2017b, 2021). The only other study known to the authors that examined BWSC in tandem with bark $\Phi$ and $\rho_{d}$ (Ilek et al., 2021) did not also find a statistically significant influence over interspecific BWSC despite a wide range in $\Phi(\sim 0.50-$ $0.80 \mathrm{~cm}^{3} \mathrm{~cm}^{-3}$ ) for five different broadleaved tree species in the southeastern United States. It may be that, so long as bark pore space is not markedly different between species - note the difference between these species $\Phi$ was $<0.10 \mathrm{~cm}^{3} \mathrm{~cm}^{-3}-$ the greater thickness of bark results in greater water storage space. The other physical traits examined in past studies for their potential to drive variability in BWSC include surface structural metrics (Van Stan et al., 2016; Ilek et al., 2017a). The studies reported that a bark with greater surface area (Ilek et al., 2017a), roughness (Van Stan et al., 2016), or microrelief (Van Stan and Levia, 2010), enabled greater retention of external (surface) water. A strong linear relationship was reported between BWSC and the bark mean ridge-to-furrow amplitude for individual trees in central Germany (Van Stan et al., 2016). A significant increase in a tree's BWSC was observed for greater bark surface areas (Ilek et al., 2017a) and for larger microrelief (Van Stan and Levia, 2010). Vertical variation in total bark thickness (Figures 4, 5) which decreased from the bottom to the top of sampled trees has been well documented in literature (Eberhardt, 2013; Liepiņš and Liepiņš, 2015; Rosell, 2019), also for silver fir and Norway spruce (Stängle et al., 2016; Stängle and Dormann, 2018). The higher BWSC of fir bark than spruce bark (especially in the middle and the top part of trees) is probably associated with a much smaller share of the outer bark in total fir bark thickness, as fir bark contained $\sim 50 \%$ less outer bark in the bottom and in the middle parts and over $70 \%$ in the top part (Figure 5). Interestingly, the bark $\Phi$ and $\rho_{d}$ were relatively constant along the stems; only slight changes (decrease in density and increase in porosity) can be observed in the top part of trees both species (Figure 5), characterized by the highest BWSC than other 


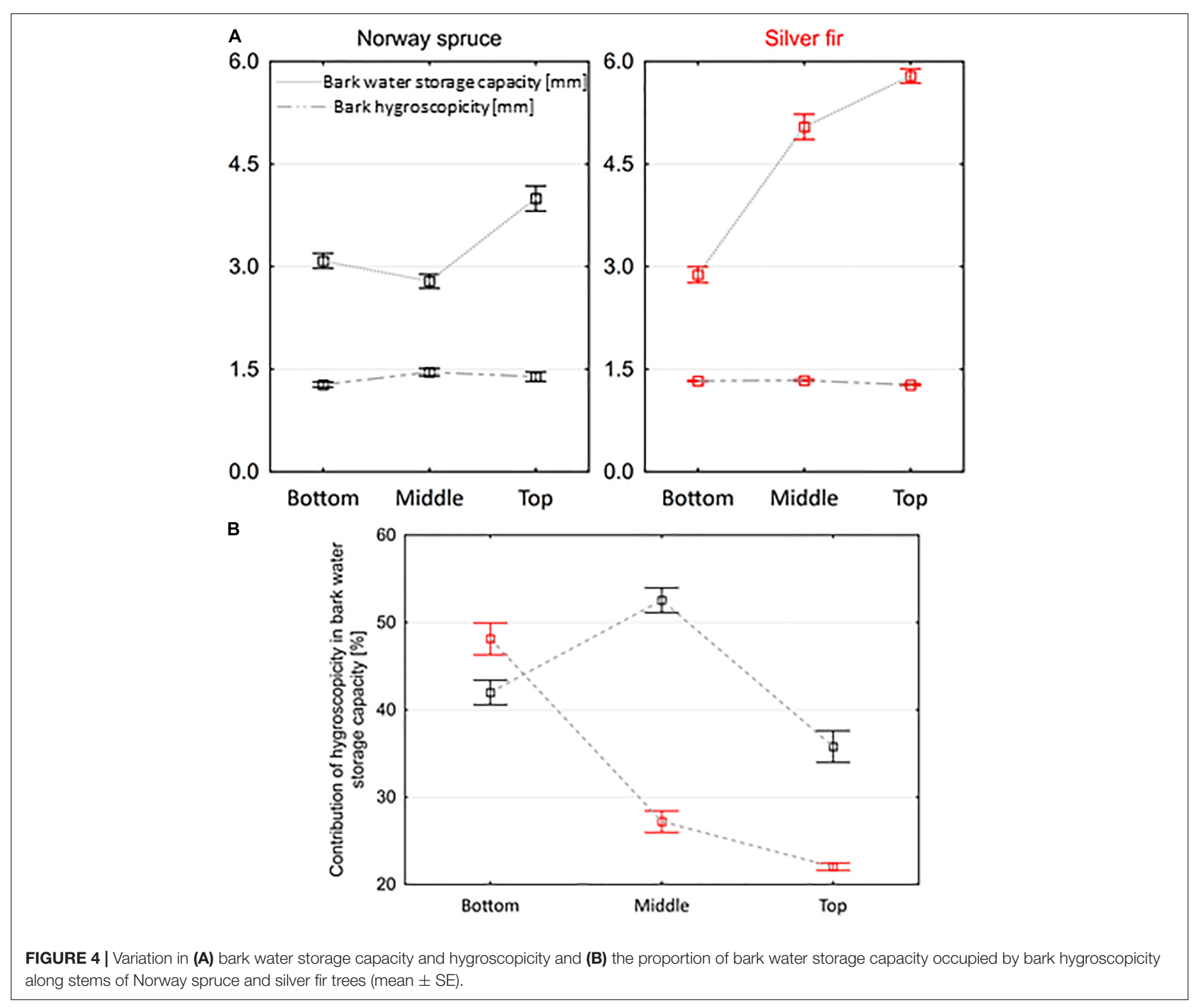

parts of trees. Thus, our results show that bark physical traits influence hydrological traits, rejecting hypothesis 3. Quilhó and Pereira (2001) for Eucalyptus globulus trees also observed a slight decrease in bark density along stems. Alternatively, Bhat (1982) found a slight increasing trend in bark density from the bottom to the top of trees for two birch species (Betula pendula and Betula pubescens). Some studies indicate a significant variation in the bark density between individual species (Miles and Smith, 2009) and differences between the density of inner and outer bark, i.e., the density of inner bark is usually less than outer bark (Meyer et al., 1981). The higher density of outer bark may be caused by the expanding periderm which rupture the outer bark cells and, second, the loss of moisture from the outermost bark tissue may result in shrinkage and cell collapse (Martin and Crist, 1970; Meyer et al., 1981; Ugulino et al., 2020). The less-dense inner bark usually has more moisture content than the moredense outer bark (Kain et al., 2020; Ugulino et al., 2020). Graves et al. (2014) observed that although the density did not differ between inner and outer bark of oaks, the moisture contents were higher in inner than outer bark. Bhat (1982) found the relationship between bark density and bark thickness of two birch species, i.e., density is positively correlated with inner and total bark thickness (probably because the sclerenchyma content of the secondary phloem substantially contributes to the density of the bark), while outer bark thickness is correlated negatively with density because thin-walled periderm cells contribute more to the increase in bark volume rather than bark weight. This agreed with our results, which found thicker and denser fir bark had an average of $73 \%$ of the inner bark which stored more water than the thinner and less dense spruce bark, which averaged $43 \%$ of the outer bark (Figure 5). The chemical composition of bark varies with tree species, tree parts, tree stress, geographic location, climate, and soil conditions (Feng et al., 2013). Legrand et al. (1996) found that bark conductivity of Norway spruce and silver fir trees and bark $\mathrm{pH}$ increased with height of trees, i.e., bark was less acid at the top than at the bottom part 


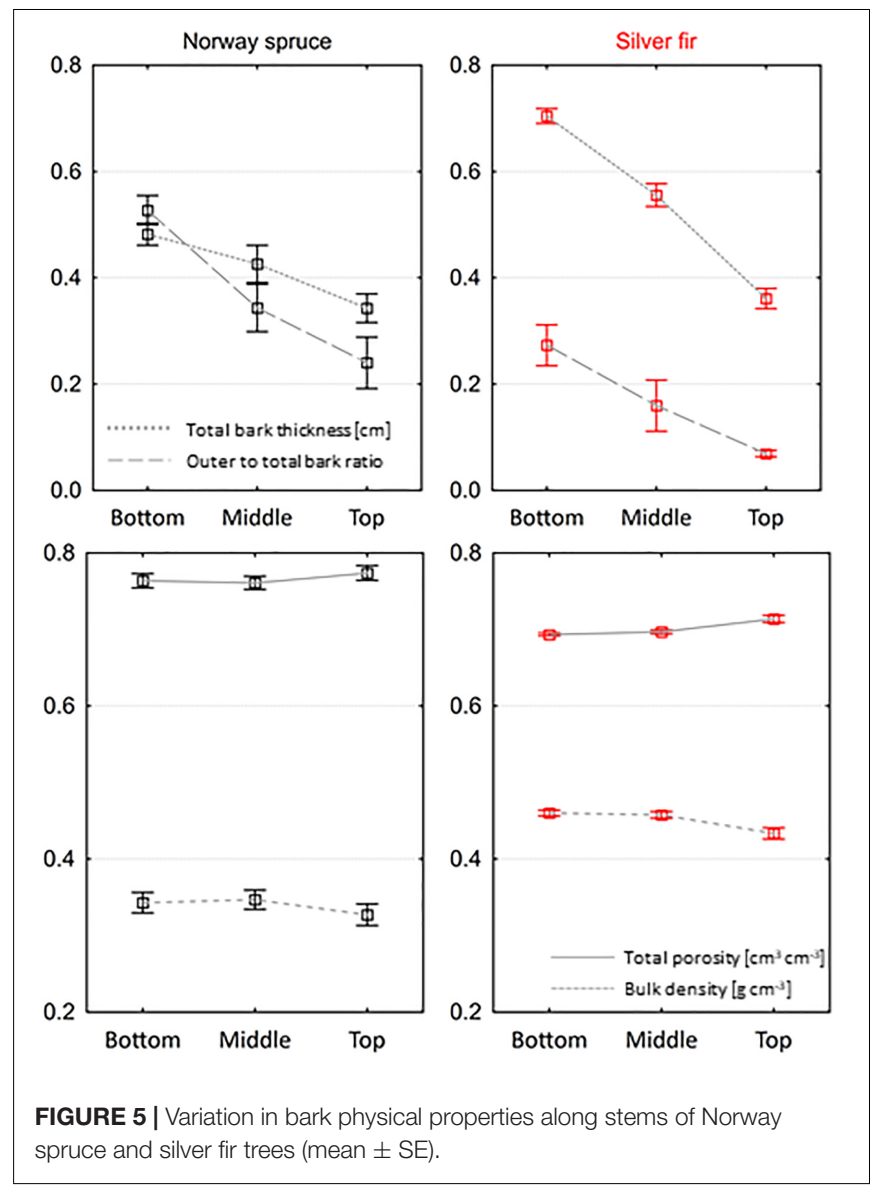

of trees. Tomczuk (1975) showed that the lignin content in Norway spruce and silver fir bark increased from the bottom to the top of trees (especially within the crown), from 23.8 at the bottom to $25.3 \%$ at the top (spruce) and 24.3 to $26.0 \%$ (fir). The higher lignin content in fir bark could also have resulted in its higher BWSC - although recent work on bark lignin content, wettability, and stemflow generation suggests that lignin's relationship to water storage capacity may depend on various other bark structural factors (Tonello et al., 2021). Lignin content can also vary between the different layers of the bark: where lignin in the inner bark is similar to the corresponding wood, while the outer bark lignin differs from the inner bark lignin (Sjostrom, 1993).

The lower density of spruce bark and the higher total porosity indicate that spruce may absorb (potentially) more water than the more dense and less porous fir bark. Indeed, it is confirmed by the bark absorbability of non-silicone bark samples (Figure 3A), which is significantly higher in spruce than in fir. The differences in bark absorbability by non-silicon and silicone bark samples indicate that the water absorption process is mainly determined by the physical and chemical properties of the outer bark. Significant differences between silicone and non-silicone bark (greater in spruce than in fir) may be caused by the share of outer bark, which was higher in spruce than in fir bark, effectively limited the water absorption by silicone bark samples. On the
TABLE 2 | General linear model analysis for bark characteristics.

\begin{tabular}{|c|c|c|c|c|c|c|}
\hline \multirow[t]{2}{*}{ Bark properties } & \multicolumn{2}{|c|}{ Tree species } & \multicolumn{2}{|c|}{ Part of tree } & \multicolumn{2}{|c|}{$\begin{array}{c}\text { Tree species } x \\
\text { part of tree }\end{array}$} \\
\hline & $\boldsymbol{F}$ & $p$ & $\boldsymbol{F}$ & $p$ & $\boldsymbol{F}$ & $p$ \\
\hline Bark water storage capacity & 95.94 & 0.000 & 74.53 & 0.000 & 43.24 & 0.000 \\
\hline Bark hygroscopicity & 2.66 & 0.106 & 2.72 & 0.070 & 2.98 & 0.055 \\
\hline $\begin{array}{l}\text { Contribution of hygroscopicity } \\
\text { in bark water storage capacity }\end{array}$ & 50.58 & 0.000 & 36.41 & 0.000 & 45.97 & 0.000 \\
\hline Bark thickness & 35.21 & 0.000 & 45.57 & 0.000 & 8.29 & 0.000 \\
\hline $\begin{array}{l}\text { Outer to total bark thickness } \\
\text { ratio }\end{array}$ & 138.22 & 0.000 & 41.58 & 0.000 & 6.04 & 0.003 \\
\hline Bulk density & 132.44 & 0.000 & 1.84 & 0.163 & 0.12 & 0.890 \\
\hline Total porosity & 96.91 & 0.000 & 2.00 & 0.140 & 0.24 & 0.789 \\
\hline
\end{tabular}

The significance effect $(p<0.05)$ is shown in bold.

other hand, the smaller differences in water absorption between silicone and non-silicone bark samples of fir are probably related to the greater density of the inner bark (compared to the inner bark of spruce) and a much lower share of outer bark. In turn, the increasing rate of water absorption along stems is related to the decreasing share of outer bark as well as the age of the bark and chemical composition. Because of the suberization of bark cells, the outer bark slows down the water absorption process. Differences in bark absorbability and absorption rate between non-silicone and silicone bark samples (Figure 3) indicate that sealing these bark surfaces not typically in contact with water should be obligatory in laboratory tests. In future investigations of bark-water relations should be distinguished and concerned mainly on outer bark, especially that outer bark is the outermost layer of trees, and as we have shown in our research, its thickness, density, and other properties (which were not examined here) have probably a direct effect on the amount of water absorbed. Furthermore, the inner bark is usually connected with wood, has a high moisture content (Reifsnyder et al., 1967; Kain et al., 2020), and its role in rainwater absorption is probably much smaller than the role of outer bark in this process. These results also reveal difficulties in comparing past research results on barkwater relations due to the lack of uniform methodology, i.e., determination of bark water storage capacity is usually by entirely submerged of bark samples in water for variable amounts of time, from 3 days (Levia and Herwitz, 2005; Valovà and Bieleszovà, 2008), 4 days (Levia and Wubbena, 2006), 7 days (Ilek et al., 2017b, 2021), 1 month (Harmon and Sexton, 1995), or until the bark sample mass remained steady for three consecutive measurements, and further immersion does not increase the bark mass by more than 5\% (Van Stan et al., 2016). The last method seems most objective, but according to Ilek et al. (2017a), the time of bark saturation until constant mass is very long and ranges from 24 to 35 days depending on tree species, and does not reflect the natural conditions. The long and unnatural bark wetting process causes that estimation of bark water storage capacity in the laboratory could differ from bark water storage capacities in the field (Levia and Herwitz, 2005). We recommend that the methods reported here (which consider sealing bark surfaces not typically in contact with 
water, place samples at their typical orientation, and simulate rainfall rather than submerge) be applied in future research on bark-rainfall interactions to improve inter-study (and interspecies) comparisons.

Vertically, we did not observe a significant change in bark hygroscopicity (i.e., hypothesis 2 was not rejected). Past research, however, has shown that there is a linear relationship between the bark hygroscopicity and the bulk density and porosity: i.e., with increasing $\rho_{d}$ and decreasing $\Phi$, bark hygroscopicity increases (Ilek et al., 2017b, 2021). This relationship is also well documented for wood (Glass and Zelinka, 2010). In this study, the lack of vertical variation in bark hygroscopicity appears to result from the low variation in $\rho_{d}$ and $\Phi$ along the stems of both species (Figure 5). On the other hand, the lack of differences in the bark hygroscopicity between species indicates that the differences in the density and porosity between species amounting to an average of $0.12 \mathrm{~g} \mathrm{~cm}^{-3}$ and $0.07 \mathrm{~cm}^{3} \mathrm{~cm}^{-3}$ do not significantly affect changes in hygroscopicity. On the other hand, vertical variability in bark water storage capacity is different between the species (increasing linearly with fir vs. a non-linear trend with spruce). This results in interspecific differences in the vertical variability of the fraction of water storage capacity occupied by hygroscopic water - being lower for the upper fir canopy compared to the stem base, but, for spruce, being higher in the mid-stem than top or bottom. As much of stemflow is generated by upper canopy, e.g., Hutchinson and Roberts (1981) found over half of stemflow is generated by the upper canopy of Douglas fir (Pseudotsuga menziesii), this higher upper-canopy water storage availability may impede stemflow generation for fir. Indeed, Abies species are reported to have low stemflow fractions: $0.7-0.8 \%$ for Abies balsamea (Plamondon et al., 1984; Courchesne and Hendershot, 1988), 0.1-0.8\% for Abies grandis (Ovington, 1954; Aussenac, 1968), and $0.01 \%$ for Abies pindrow (Negi et al., 1998). On the other hand, for spruce, stemflow generation must overcome a smaller fraction of a lower BWSC in the upper canopy. If this is overcome, the mid-canopy water storage fraction may already be $50 \%$ saturated (hygroscopically), enhancing the possibility of uppercanopy branchflows draining down to the surface as stemflow. This builds on previous work that suggests the role additional branch biomass plays on stemflow generation depends on the bark hydrological properties covering those branches (Levia et al., 2015; Sadeghi et al., 2017; Van Stan et al., 2020). Depending on bark hydrological properties and patterns in the canopy, additional branch area may increase drainage as stemflow as Levia et al. (2015) observed for saplings and Sadeghi et al. (2017) observed for a smooth-barked invasive tree - or, this additional branch area may impede stemflow generation (as reviewed in Van Stan et al., 2020). However, to parameterize hydrologic models that may predict stemflow based on bark properties, further studies on the relationship between bark internal structure, hygroscopic properties, bark water storage capacity, and stemflow production are needed.

Besides being a part of the canopy water balance, bark is a habitat for many microbes (Magyar, 2008; Lambais et al., 2014), meiofauna (Ptatscheck et al., 2015, 2018), and epiphytic vegetation (Zarate-García et al., 2020;
Porada and Giordani, 2021) - all of which will, at least in part, depend on moisture availability. Bark water storage may support epiphytic vegetation, yet little work exists that explicitly tests the relationship between epiphytic vegetation and bark-water interactions. A process-based model application for a site with detailed non-vascular epiphyte data (Sardinia, Italy) suggests that "switching off" BWSC may reduce epiphyte net primary productivity by $21 \%$, and reduce physiological diversity of the epiphyte community by 23\% (Porada and Giordani, 2021). For vascular epiphytic vegetation, a recent study found a preference by orchids for host trees with larger BWSC (and bark $\Phi$ ) - even at the expense of bark structures previously believed to be beneficial for orchid attachment (Zarate-García et al., 2020). Micro-habitats in the bark have been described by Magyar (2008) that appear to be linked to precipitation and hygroscopic moisture (Magyar et al., 2021), and may shape the bark fungal and micro-faunal communities. Hygroscopic fractions may be especially important to the formation/sustenance of bark microhabitats (even more so than rainwater storage), because it is present and potentially available during dry periods and may be meaningful during drought. Hygroscopicity may also be complementary to bark water vapor conductance - something recently linked to drought resistance for the plant itself (Wolfe, 2020).

\section{CONCLUSION}

This study evaluated vertical changes in bark properties and hydrology along the stems of two coniferous tree species (Norway spruce and silver fir) in southern Poland. Results revealed the following:

(1) The physical and hydrological properties of bark differed between species, i.e., spruce bark was $\sim 32 \%$ thinner than fir bark, contained $\sim 45 \%$ more external than internal bark, also had $\sim 26 \%$ less density, $9 \%$ greater porosity, and $\sim 16 \%$ lower water capacity, and the proportion of bark water storage capacity occupied by bark hygroscopicity was $\sim 28 \%$ higher in spruce than fir bark. The interspecific variation in hydro-physical properties of bark was also found between individual tree parts (except for bark hygroscopicity).

(2) In both species, only some hydro-physical properties changed along the stems, i.e., the thickness and the ratio of outer-to-total bark thickness decreased with height, accompanied by an increase in the bark water storage capacity. In contrast, the bark's density, porosity, and hygroscopicity remained relatively constant along stems. These results indicate that bark water storage capacity may primarily be influenced by its thickness and the share of the outer bark, while the bulk density and porosity influence mainly the bark hygroscopicity; thus, all examined physical properties of bark affected the contribution of hygroscopicity in bark water storage capacity.

(3) Differences in bark absorbability and absorption rate between bark samples where the cuts were sealed vs. not sealed (with silicon) indicate that the properties of outer bark mainly determine the water absorption process. 
Thus, future investigation of bark-water relations should be focused primarily on the outer bark.

\section{DATA AVAILABILITY STATEMENT}

The original contributions presented in the study are included in the article/supplementary material, further inquiries can be directed to the corresponding author.

\section{REFERENCES}

Anosike, J. C., Nwoke, B. E., Okere, A. N., Oku, E. E., Asor, J. E., Emmy-Egbe, I. O., et al. (2007). Epidemiology of tree-hole breeding mosquitoes in the tropical rainforest of Imo State, south-east Nigeria. Ann. Agric. Environ. Med. 14, 31-38.

Aubrey, D. P. (2020). "Relevance of precipitation partitioning to the tree water and nutrient balance," in Precipitation Partitioning by Vegetation: A Global Synthesis, eds J. Van Stan II, E. Gutmann, and J. Friesen (Switzerland: Springer), $147-162$.

Aussenac, G. (1968). Interception des précipitations par le couvert forestier. Ann. Sci. For. 25, 135-156.

Berry, Z. C., Emery, N. C., Gotsch, S. G., and Goldsmith, G. R. (2019). Foliar water uptake: processes, pathways, and integration into plant water budgets. Plant Cell Environ. 42, 410-423. doi: 10.1111/pce.13439

Bhat, K. M. (1982). Anatomy, basic density and shrinkage of birch bark. IAWA J. 3, 207-213. doi: 10.1163/22941932-90000841

Campellone, S. V. (2018). An Investigation into the Factors Affecting Street Tree Rainfall Interception. Masters Thesis. Philadelphia, PA: Drexel University.

Carmichael, M. J., White, J. C., Cory, S. T., Berry, Z. C., and Smith, W. K. (2020). Foliar water uptake of fog confers ecophysiological benefits to four common tree species of southeastern freshwater forested wetlands. Ecohydrology 13:e2240. doi: 10.1002/eco.2240

Courchesne, F., and Hendershot, W. H. (1988). Apport en sulfate et en eau à la surface du sol sous quatre espèces arborescentes. Nat. Can. 115, 57-63.

Davies-Barnard, T., Valdes, P. J., Jones, C. D., and Singarayer, J. S. (2014). Sensitivity of a coupled climate model to canopy interception capacity. Clim. Dyn. 42, 1715-1732. doi: 10.1007/s00382-014-2100-1

DeBary, H. A. (1853). Untersuchungen Über die Brandpilze und die Durch sie Verursachten Krankheiten der Pflanzen mit Rücksicht auf das Getreide und Andere Nutzpflanzen. Habilitation. Muller, Berlin.

Eberhardt, T. L. (2013). Longleaf pine inner bark and outer bark thicknesses: measurement and relevance. South. J. Appl. For. 37, 177-180. doi: 10.5849/sjaf. 12-023

Feng, S., Cheng, S., Yuan, Z., Leitch, M., and Xu, C. C. (2013). Valorization of bark for chemicals and materials: a review. Renew. Sustain. Energy Rev. 26, 560-578. doi: 10.1016/j.rser.2013.06.024

Glass, S. V., and Zelinka, S. L. (2010). Moisture Relations and Physical Properties of Wood. Wood Handbook: Wood as an Engineering Material: Chapter 4. Centennial ed. General Technical Report FPL; GTR-190. Madison, WI: US Dept. of Agriculture,

Graves, S. J., Rifai, S. W., and Putz, F. E. (2014). Outer bark thickness decreases more with height on stems of fire-resistant than fire-sensitive Floridian oaks (Quercus spp.; Fagaceae). Am. J. Bot. 101, 2183-2188. doi: 10.3732/ajb.1400412

Harmon, M. E., and Sexton, J. (1995). Water balance of conifer logs in early stages of decomposition. Plant Soil 172, 141-152. doi: 10.1007/BF00020868

Herwitz, S. R. (1985). Interception storage capacities of tropical rainforest canopy trees. J. Hydrol. 77, 237-252. doi: 10.1016/0022-1694(85)90209-4

Herwitz, S. R. (1987). Raindrop impact and water flow on the vegetative surfaces of trees and the effects on stemflow and throughfall generation. Earth Surf. Process. Landf. 12, 425-432. doi: 10.1002/esp.3290120408

Hutchinson, I., and Roberts, M. C. (1981). Vertical variation in stemflow generation. J. Appl. Ecol. 18, 521-527. doi: 10.2307/2402413

Ilek, A., Kucza, J., and Morkisz, K. (2017b). Hygroscopicity of the bark of selected forest tree species. iForest 10, 220-226. doi: 10.3832/ifor1979-009

\section{AUTHOR CONTRIBUTIONS}

$\mathrm{AI}, \mathrm{KM}$, and $\mathrm{JK}$ : conceptualization. $\mathrm{AI}$ and $\mathrm{KM}$ : sample collection, preparation for analysis, and laboratory research. AI and $\mathrm{JK}$ : methodology. $\mathrm{AI}$ and $\mathrm{JV}$ : analysis and interpretation of data and writing - original draft preparation, review, and editing. AI: resources. JV: writing - language review and editing. All authors contributed to manuscript revision, read, and approved the submitted version.

Ilek, A., Kucza, J., and Morkisz, K. (2017a). Hydrological properties of bark of selected forest tree species. Part 2: interspecific variability of bark water storage capacity. Folia For. Pol. Ser. A. For. 59, 110-122. doi: 10.1515/ffp-2017-0011

Ilek, A., Siegert, C. M., and Wade, A. (2021). Hygroscopic contributions to bark water storage and controls exerted by internal bark structure over water vapor absorption. Trees 35, 831-843. doi: 10.1007/s00468-021-0 2084-0

Ilek, A., Szostek, M., Kucza, J., Stanek-Tarkowska, J., and Witek, W. (2019). The water absorbability of beech (Fagus sylvatica 1.) and fir (Abies alba mill.) organic matter in the forest floor. Ann. For. Res. 62, 21-32. doi: 10.15287/afr.2018.1161

Kain, G., Morandini, M., Barbu, M.-C., Petutschnigg, A., and Tippner, J. (2020). Specific gravity of inner and outer larch bark. Forests 11:1132. doi: 10.3390/ f11111132

Klamerus-Iwan, A., Link, T. E., Klein, R. F., and Van Stan, J. II (2020). "Storage and routing of precipitation through canopies," in Precipitation Partitioning by Vegetation: A Global Synthesis, eds J. Van Stan II, E. Gutmann, and J. Friesen (Switzerland: Springer), 17-34.

Kucza, J., and Urbaś, J. (2005). Water absorption of organic matter taken from horizons of ectohumus of forest soils under Norway spruce stands. EJPAU For. $8,50-58$.

Lambais, M. R., Lucheta, A. R., and Crowley, D. E. (2014). Bacterial community assemblages associated with the phyllosphere, dermosphere, and rhizosphere of tree species of the Atlantic forest are host taxon dependent. Microb. Ecol. 68, 567-574. doi: 10.1007/s00248-014-0433-2

Legrand, I., Asta, J., and Goudard, Y. (1996). Variations in bark acidity and conductivity over the trunk length of silver fir and Norway spruce. Trees 11, 54-58. doi: 10.1007/s004680050058

Levia, D. F., and Herwitz, S. R. (2005). Interspecific variation of bark water storage capacity of three deciduous tree species in relation to stemflow yield and solute flux to forest soils. Catena 64, 117-137. doi: 10.1016/j.catena.2005.08.001

Levia, D. F., Michalzik, B., Näthe, K., Bischoff, S., Richter, S., and Legates, D. R. (2015). Differential stemflow yield from European beech saplings: the role of individual canopy structure metrics. Hydrol. Process. 29, 43-51. doi: 10.1002/ hyp. 10124

Levia, D. F., and Wubbena, N. P. (2006). . Vertical variation of bark water storage capacity of Pinus strobus L.(Eastern white pine) in southern Illinois. Northeast. Nat. 13, 131-137.

Liepiņš, J., and Liepiņš, K. (2015). Evaluation of bark volume of four tree species in Latvia. Res. Rural Dev. 2, 22-28.

Liu, S. (1998). Estimation of rainfall storage capacity in the canopies of cypress wetlands and slash pine uplands in North-Central Florida. J. Hydrol. 207, 32-41. doi: 10.1016/S0022-1694(98)00115-2

Llorens, P., and Gallart, F. (2000). A simplified method for forest water storage capacity measurement. J. Hydrol. 240, 131-144. doi: 10.1016/S0022-1694(00) 00339-5

Loram-Lourenco, L., Farnese, F. D. S., Sousa, L. F. D., Alves, R. D. F. B., Andrade, M. C. P. D., Almeida, S. E. D. S., et al. (2020). A structure shaped by fire, but also water: ecological consequences of the variability in bark properties across 31 species from the brazilian cerrado. Front. Plant Sci. 10:1718. doi: $10.3389 /$ fpls.2019.01718

Magyar, D. (2008). The tree bark: a natural spore trap. ASP Appl. Biol. 89, 7-16.

Magyar, D., Van Stan, J. T., and Sridhar, K. R. (2021). Hypothesis and theory: fungal spores in stemflow and potential bark sources. Front. For. Global Change 4:19.

Maguire, B. (1971). Phytotelmata: biota and community structure determination in plant-held waters. Annu. Rev. Ecol. Syst. 2, 439-464. 
Martin, R. E., and Crist, J. B. (1970). Elements of bark structure and terminology. Wood Fiber Sci. 2, 269-279.

Meyer, R. W., Kellogg, R. M., and Warren, W. G. (1981). Relative density, equilibrium moisture content, and dimensional stability of western hemlock bark. Wood Fiber Sci. 13, 86-96.

Miles, P. D., and Smith, W. B. (2009). Specific Gravity and Other Properties of Wood and Bark for 156 Tree Species Found in North America (Vol. 38). Washington, DC: US Department of Agriculture, Forest Service, Northern Research Station.

Miller, G., Hartzell, S., and Porporato, A. (2021). Ecohydrology of epiphytes: modeling water balance, CAM photosynthesis, and their climate impacts. Ecohydrology 14:e2275. doi: 10.1002/eco.2275

Negi, G. C. S., Rikhari, H. C., and Garkoti, S. C. (1998). The hydrology of three high-altitude forests in Central Himalaya, India: a reconnaissance study. Hydrol. Process. 12, 343-350.

Nowak, D. J., Coville, R., Endreny, T., Abdi, R., and Van Stan, J. T. II (2020). "Valuing urban tree impacts on precipitation partitioning," in Precipitation Partitioning by Vegetation: A Global Synthesis, eds J. Van Stan II, E. Gutmann, and J. Friesen (Switzerland: Springer), 253-268.

Ovington, J. D. (1954). A comparison of rainfall in different woodlands. Forestry 27, 41-53. doi: 10.1093/forestry/27.1.41

Plamondon, A. P., Prévost, M., and Naud, R. C. (1984). Interception de la pluie dans la sapinière à bouleau blanc, Forêt Montmorency. Can. J. For. Res. 14, 722-730. doi: $10.1139 / \mathrm{x} 84-129$

Porada, P., and Giordani, P. (2021). Bark water storage plays key role for growth of Mediterranean epiphytic lichens. Front. For. Glob. Change 4:668682. doi: $10.3389 /$ ffgc. 2021.668682

Porada, P., Van Stan, J. T., and Kleidon, A. (2018). Significant contribution of non-vascular vegetation to global rainfall interception. Nat. Geosci. 11, 563-567. doi: 10.1038/s41561-018-0176-7

Ptatscheck, C., Dümmer, B., and Traunspurger, W. (2015). Nematode colonisation of artificial water-filled tree holes. Nematology 17, 911-921. doi: 10.1163/ 15685411-00002913

Ptatscheck, C., Milne, P. C., and Traunspurger, W. (2018). Is stemflow a vector for the transport of small metazoans from tree surfaces down to soil? BMC Ecol. 18:43. doi: 10.1186/s12898-018-0198-4

Quilhó, T., and Pereira, H. (2001). Within and between-tree variation of bark content and wood density of Eucalyptus globulus in commercial plantations. IAWA J. 22, 255-265. doi: 10.1163/22941932-9000 0283

Reifsnyder, W. E., Harrington, L. P., and Spalt, K. W. (1967). Thermophysical Properties of Bark of Shortleaf, Longleaf, and Red Pine. Yale University Forestry Bulletin Number 70. New Haven, CT: Yale University School of Forestry.

Rosell, J. A. (2019). Bark in woody plants: understanding the diversity of a multifunctional structure. Integr. Comp. Biol. 59, 535-547. doi: 10.1093/icb/ icz057

Rosell, J. A., Castorena, M., Laws, C. A., and Westoby, M. (2015). Bark ecology of twigs vs. main stems: functional traits across eighty-five species of angiosperms. Oecologia 178, 1033-1043. doi: 10.1007/s00442-015-3307-5

Rowlandson, T., Gleason, M., Sentelhas, P., Gillespie, T., Thomas, C., and Hornbuckle, B. (2015). Reconsidering leaf wetness duration determination for plant disease management. Plant Dis. 99, 310-319. doi: 10.1094/PDIS-05-140529-FE

Sadeghi, S. M. M., Van Stan, J. T. II, Pypker, T. G., and Friesen, J. (2017). Canopy hydrometeorological dynamics across a chronosequence of a globally invasive species, Ailanthus altissima (Mill., tree of heaven). Agric. For. Meteorol. 240, 10-17. doi: 10.1016/j.agrformet.2017.03.017

Sjostrom, E. (1993). Wood chemistry. Fundamentals and Applications, 2nd Edn. Cambridge, MA: Academic Press, 293.

Stängle, S. M., and Dormann, C. F. (2018). Modelling the variation of bark thickness within and between European silver fir (Abies alba Mill.) trees in southwest Germany. For. Int. J. For. Res. 91, 283-294. doi: 10.1093/forestry/ cpx047
Stängle, S. M., Weiskittel, A. R., Dormann, C. F., and Brüchert, F. (2016). Measurement and prediction of bark thickness in Picea abies: assessment of accuracy, precision, and sample size requirements. Can. J. For. Res. 46, 39-47. doi: 10.1139/cjfr-2015-0263

Tomczuk, R. I. (1975). Skład chemiczny drzew. Folia For. Pol. Ser. B 12, 5-14.

Tonello, K. C., Campos, S. D., de Menezes, A. J., Bramorski, J., Mathias, S. L., and Lima, M. T. (2021). How is bark absorbability and wettability related to stemflow yield? Observations from isolated trees in the Brazilian cerrado. Front. For. Global Change 4:650665. doi: 10.3389/ffgc.2021.650665

Ugulino, B., Cáceres, C. B., Hernández, R. E., and Blais, C. (2020). Influence of temperature and moisture content on bark/wood shear strength of black spruce and balsam fir logs. Wood Sci. Technol. 54, 963-979. doi: 10.1007/s00226-02001198-x

Valovà, M., and Bieleszovà, S. (2008). Interspecific variations of bark's water storage capacity of chosen types of trees and the dependence on occurrence of epiphytic mosses. GeoSci. Eng. 2008, 45-51.

Van Stan, J. T., Hildebrandt, A., Friesen, J., Metzger, J. C., and Yankine, S. A. (2020). "Spatial Variability and temporal stability of local net precipitation patterns," in Precipitation Partitioning by Vegetation: A Global Synthesis, eds J. Van Stan II, E. Gutmann, and J. Friesen (Switzerland: Springer), 89-104.

Van Stan, J. T., and Levia, D. F. Jr. (2010). Inter-and intraspecific variation of stemflow production from Fagus grandifolia Ehrh.(American beech) and Liriodendron tulipifera L.(yellow poplar) in relation to bark microrelief in the eastern United States. Ecohydrology 3, 11-19. doi: 10.1002/eco.83

Van Stan, J. T., Lewis, E. S., Hildebrandt, A., Rebmann, C., and Friesen, J. (2016). Impact of interacting bark structure and rainfall conditions on stemflow variability in a temperate beech-oak forest, central Germany. Hydrol. Sci. J. 61, 2071-2083. doi: 10.1080/02626667.2015.1083104

Van Stan, J. T., Ponette-Gonzalez, A. G., Swanson, T., and Weathers, K. C. (2021). Concepts and Questions: throughfall and stemflow are major hydrologic highways for particulate traffic through tree canopies. Front. Ecol. Environ. 19, 404-410.

Wolfe, B. T. (2020). Bark water vapour conductance is associated with drought performance in tropical trees. Biol. Lett. 16:20200263. doi: 10.1098/rsbl.2020. 0263

Wolfe, B. T., and Kursar, T. A. (2015). Diverse patterns of stored water use among saplings in seasonally dry tropical forests. Oecologia 179, 925-936. doi: 10.1007/ s00442-015-3329-z)

Zarate-García, A. M., Noguera-Savelli, E., Andrade-Canto, S. B., ZavaletaMancera, H. A., Gauthier, A., and Alatorre-Cobos, F. (2020). Bark water storage capacity influences epiphytic orchid preference for host trees. Am. J. Bot. 107, 726-734. doi: 10.1002/ajb2.1470

Zhang, H., Fu, C., Liao, A., Zhang, C., Liu, J., Wang, N., et al. (2021). Exploring the stemflow dynamics and driving factors at both inter-and intra-event scales in a typical subtropical deciduous forest. Hydrol. Process. 35:e14091. doi: 10.1002/ hyp.14091

Conflict of Interest: The authors declare that the research was conducted in the absence of any commercial or financial relationships that could be construed as a potential conflict of interest.

Publisher's Note: All claims expressed in this article are solely those of the authors and do not necessarily represent those of their affiliated organizations, or those of the publisher, the editors and the reviewers. Any product that may be evaluated in this article, or claim that may be made by its manufacturer, is not guaranteed or endorsed by the publisher.

Copyright $(2021$ Ilek, Van Stan, Morkisz and Kucza. This is an open-access article distributed under the terms of the Creative Commons Attribution License (CC BY). The use, distribution or reproduction in other forums is permitted, provided the original author(s) and the copyright owner(s) are credited and that the original publication in this journal is cited, in accordance with accepted academic practice. No use, distribution or reproduction is permitted which does not comply with these terms. 